\title{
EVALUATION OF IN-VITRO ANTIBACTERIAL ACTIVITY OF Cinnamomum zeylanicum EXTRACT ON DIFFERENT MICROORGANISMS OF THE DENTAL PLAQUE
}

\author{
Fouad H.M. *, Mahmood A.A.** and Siti Noor Aishah Bt Samin*** \\ *Department of Oral Pathology, Oral Medicine\& Periodontology,Faculty of Dentistry, \\ University of Malaya \\ **Department of Molecular Medicine, Faculty of Medicine, \\ University of Malaya 50603 Kuala Lumpur, Malaysia
}

\begin{abstract}
The present study was conducted to evaluate the antibacterial activity of aqueous and ethanol extracts of Cinnamomum zeylanicum on different types of dental plaque microorganisms. Screening study was performed to detect the potential antibacterial activity against $S$. aureus, E. coli, S. mutans, L. casei, B. fragilis, A. actinomycetemcomitans and dental plaque pool samples. From the screening test, values of Minimum Inhibitory Concentration (MIC) were determined. The lowest MIC value was $25 \mathrm{mg} / \mathrm{ml}$ of aqueous and $12.5 \mathrm{mg} / \mathrm{ml}$ of ethanol extract for $S$. aureus. The highest MIC values were seen in $A$. actinomycetemcomitans and dental plaque anaerobic pool samples with $300 \mathrm{mg} / \mathrm{ml}$ of aqueous extract and $150 \mathrm{mg} / \mathrm{ml}$ of ethanol extract. The MIC values for aqueous extracts ranged from 25 to $300 \mathrm{mg} / \mathrm{ml}$ whereas for ethanol extract it ranged from 12.5 to $150 \mathrm{mg} / \mathrm{ml}$. The high concentration of ethanol extract, $100 \mathrm{mg} / \mathrm{ml} \mathrm{in} \mathrm{the}$ fixed plant concentration test, showed the strongest inhibition effect for all the organisms tested. Generally, the ethanol extract of Cinnamomum zeylanicum demonstrated a stronger antibacterial activity compared to the aqueous extract. This study also compared the antibacterial activity of chlorhexidine with that of the plant extracts. Chlorhexidine showed a higher antibacterial effect on the microorganisms, with almost all organisms inhibited.
\end{abstract}

Key words: Cinnamomum; dental plaque; Chlorhexidine.

\section{Introduction}

Dental plaque is a thin whitish or pale yellow biofilm that builds up on the teeth. These biofilms are complex aggregation of diverse microorganisms. Overgrowth or imbalance of the dental plaque microbial communities will lead to the growth of more pathological organisms deeper inside the bacterial matrix of plaque biofilms. ${ }^{1}$ Different degrees of pathological bacterial that colonizes the tooth and gingiva at different site will results in different types of oral diseases. The oralenvironment enhancing the growth of acidogenic and aciduric microorganism's results tooth decay and dental carries which is characterized by irreversible solubilization of tooth mineral by acid produced by

Corresponding author: Department of Oral Pathology, Oral Medicine\& Periodontology,Faculty of Dentistry, University of Malaya 50603 Kuala Lumpur, Malaysia 
these organisms. ${ }^{2}$ Apart from dissoluting minerals from teeth, the microbial community also affects the gums adjacent to teeth causing periodontal diseases. This diseases occurred when the dental plaque organisms induce inflammatory responses due to various compounds elicited such as toxins in the tissue. Same time are responsible for loss of perindontal tissue, pocket formation and loss of teeth. Periodontal diseases are divided into two general groups which are gingivitis and periodontitis. $^{3}$

Numerous attempts have been made to use antibacterial agents to control the microbial causes of periodontal disease ${ }^{4}$. Antimicrobial agents are chemotherapeutic agents that reduce the amount of bacteria present, either by specifically targeting certain organisms or by non-specifically reducing all bacteria. The drugs made from the chemicals produced many side effects but the majority of the drugs extracted from the natural sources such as herbal extract are devoid many serious side effects, beside that this drug has a good therapeutic benefit. ${ }^{5}$ Cinnamomum zeylanicum, also known as cinnamon, is a small ever-green tree with the height of 10-15 meters tall. It is one of the world's oldest spices belonging to the Lauraceae family with the genus Cinnamomum. There is hundreds of cinnamon species where most of the species are aromatic, comprises from this genus and Cinnamomum zeylanicum, with the synonym Cinnamomum verum is among them. This plant originated from Sri Lanka and Southern India ${ }^{6}$ where the best cinnamon was grown and produced but it was also commercially grown in India, Indonesia, Vietnam, Madagascar and Egypt. The most used part of the Cinnamomum zeylanicum tree is the stem bark, which is widely used as spice. Each part of the Cinnamomum zeylanicum plant has a significant chemical composition that varies from one another. The major constituents of the stem bark is cinnamaldehyde, which make up $75 \%$ of the total bark constituents. ${ }^{7}$ Other chemical components present in the bark are cinnamyl acetate, eugenol, cryophyllene and benzyl benzoate. Cinnamomum zeylanicum extracts have the widest spectrum of bacterial inhibition activity where its antibacterial properties can inhibit the growth of many types of bacteria compared to other plants. $^{8,9}$ In previous studies, Cinnamomum zeylanicum extracts can inhibit gram positive and gram negative bacteria with its low concentrations. ${ }^{10},{ }^{11}$ This promising antibacterial activity of cinnamon causes cinnamon to be studied constantly with a wider range of bacteria. This study was driven based on a few main objectives where evaluating the antibacterial activity was the main goal. The aims were to evaluate the antibacterial activity of Cinnamomum zeylanicum aqueous extract and ethanol extracts on different microorganisms of the dental plaque and to compare the overall effects of Cinnamomum zeylanicum extracts against an antibacterial mouthwash, Oradex containing antibacterial agent Chlorhexidine.

\section{Materials And Methods}

\section{Preparation of Plant Extracts}

Cinnamomum zeylanicum dried stem bark was purchased from a local market and extracted using two types of solvents which is water (Aqueous Extract) and ethanol (Ethanol Extract). Both extractions require different procedures. Both extracts were submitted to lyophilization by a freezedryer to produce powdered forms of the extracts. Lyophilization removes the solvents from the solutes and stabilizes the formulation so that it can retain satisfactory pharmacological activity during longterm storage. The freeze-dried products were stored in sterile universal bottles and refrigerated $\left(-4^{\circ} \mathrm{C}\right)$ until time of use.

\section{Dental Plaque Microorganisms}

Six types of microorganisms used in this study where 2 microorganisms were used as internal control whereas 4 microorganisms represent dental plaque bacteria. The internal control organisms were Staphylococcus aureus (ATCC 25923) and Escherichia coli (ATCC 25922) that was obtained from the Microbiology Laboratory, Department of Molecular Medicine, University Malaya. The dental plaque organisms' whichwas Actinobacillus actinomycetemcomitans, Bacteroides fragilis, Streptococcus mutans and Lactobacillus casei was obtained from the Clinical Diagnostic Laboratory (CDL) of University Malaya Medical Center, Kuala Lumpur. These organisms were standardized to a fix amount of $1 \times 10^{8}$ cells $/ \mathrm{ml}$ after an overnight incubation with the help of hemocytometer, before these organisms were subjected to the antibacterial test later on. Apart from these microorganisms, a dental plaque pool sample was also obtained, where dental plaques were extracted randomly from the mouth and cultured in Brain Heart Infusion (BHI) broth and THIO Glycolate broth. These broths were chosen to grow aerobic, anaerobic and facultative bacteria respectively.

\section{Experimental Controls}


The positive control used throughout this study was Oradex antibacterial mouthwash, that was purchased from the Student Dental Clinic, Faculty of Dental, University Malaya. On the other hand, sterile distilled water was used as the negative control.

\section{Experimental Procedures}

\section{Disk Diffusion Test:}

The Diameter of Inhibitory Zone (DIZ) for all the disks (positive and negative control, two aqueous extracts and two ethanol extracts) was observed where clear zones (complete inhibition) were seen on the agar and the diameters were measured using a ruler to the nearest millimeter $(\mathrm{mm})$ readings. This test was done in duplicates.

\section{Minimum Inhibitory Concentration (MIC) Test}

The minimum inhibition concentration values were also studied for these organisms in order to determine the lowest concentration of plant extracts that can inhibit visible growth of these tested organisms after an overnight incubation. The lowest plant concentration that managed to inhibit the visible growth of the tested organisms was defined as the Minimum Inhibitory Concentration values. This test was also done in duplicates at different time.

\section{Fix Plant Concentration Test}

The procedures involved in this test are the opposite of the procedures involved in MIC where the bacterial dilution was done first instead of plant extracts concentration. The results will defined the lowest bacterial concentration and the number of bacteria that can be inhibited by the fixed plant concentration used.

Table 1: The average Diameter of Inhibition Zone (DIZ) of various disk for the two independent Disk Diffusion tests seen on agar plate for each type of organisms tested.

\begin{tabular}{|c|c|c|c|c|c|c|}
\hline \multirow{2}{*}{ Organism } & \multicolumn{2}{|c|}{$\begin{array}{l}\text { Aqueous } \\
\text { Extract } \\
\text { (mg/ml) }\end{array}$} & \multicolumn{2}{|c|}{$\begin{array}{l}\text { Ethanol } \\
\text { Extract } \\
\text { (mg/ml) }\end{array}$} & \multirow{2}{*}{$\begin{array}{c}\text { Oradex } \\
\text { Mouthw } \\
\text { ash } \\
(+) \text { contro } \\
\text { | }\end{array}$} & \multirow{2}{*}{$\begin{array}{c}\text { Distilled } \\
\text { water } \\
(-) \text { control }\end{array}$} \\
\hline & 200 & 100 & 200 & 100 & & \\
\hline S. aurcus & 10 & 9 & 16 & 14 & 22.5 & - \\
\hline E. coli & 11 & - & 14 & 11.5 & 20 & - \\
\hline S. mutans & 12 & 8.5 & 13.5 & 10 & 15 & - \\
\hline L. casei & 9 & - & 11 & 6.5 & 14 & - \\
\hline B. frugilis & 8 & 7 & 14.5 & 11 & 16 & - \\
\hline $\begin{array}{l}\text { A.actionnye- } \\
\text { temcomitans }\end{array}$ & - & - & - & - & 9 & - \\
\hline $\begin{array}{l}\text { Dental plaque } \\
\text { (Aerobic) }\end{array}$ & - & - & 11 & - & 13.5 & $=$ \\
\hline $\begin{array}{l}\text { Dental plaque } \\
\text { (Facultative) }\end{array}$ & - & - & 8 & - & 11 & - \\
\hline $\begin{array}{l}\text { Dental plaque } \\
\text { (Anaerobic) }\end{array}$ & - & - & 9 & - & 13 & - \\
\hline
\end{tabular}

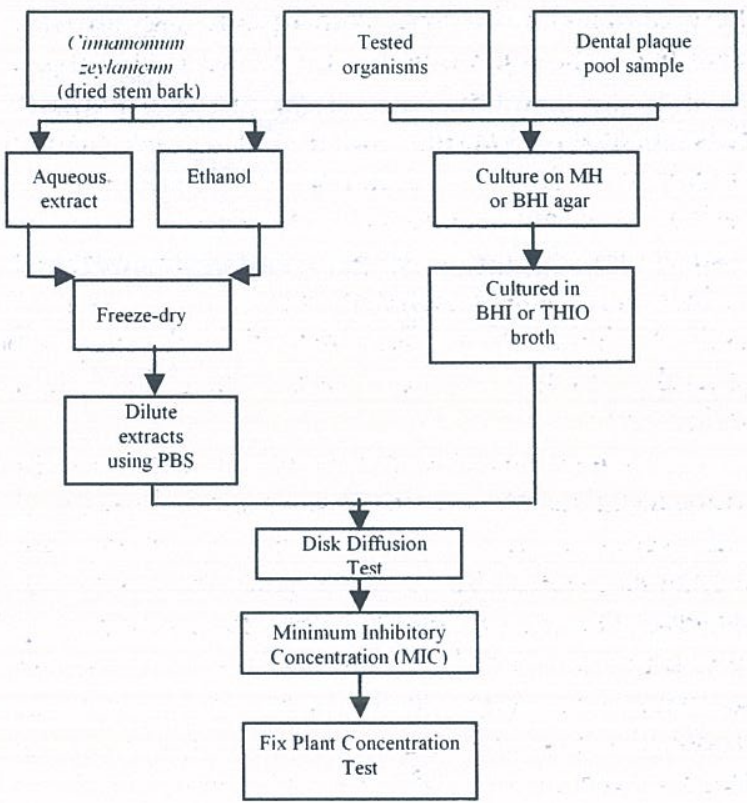

Figure 1: Flow chart demonstrating the procedures involved in this study

\section{Results}

1- Disk Diffusion Test

Table 1 shows the diameter of inhibition zones seen on agar according to each of the organisms tested. For the $S$. aureus, $S$. mutans and $B$. fragilis plates, there are zones seen around the tested disks except the negative control disk. Higher concentration of plant extract showed a larger diameter of inhibition created compared to the lower concentration of plant extract and the ethanol extracts showed a greater inhibition in comparisons to the aqueous extracts. E. coli and $L$. case $i$ showed inhibition zones for the entire plant extracts disk tested except for the $100 \mathrm{mg} / \mathrm{ml}$ of aqueous extract disk where there was no zone seen around the $\operatorname{disk} A$. actinomycetemcomitans showed resistance towards all the plant extracts disk because no zones can be identified on this organism plate. On the other hand, the dental plaque pool samples showed no inhibition zones for the entire plant extracts disk except for the higher concentration of ethanol extract which is 200 $\mathrm{mg} / \mathrm{ml}$. For the positive control disk, inhibition zones can be seen for all the organisms tested. The largest inhibition zone which is $22.5 \mathrm{~mm}$ was produced by $S$. aureus whereas the smallest zone identified from $A$. actinomycetemcomitans, with $9 \mathrm{~mm}$. 
The negative control disk, inoculated with sterile distilled water doesn't inhibit the tested organisms; therefore no inhibition zones can be seen around every negative control disks used.
2- Minimum Inhibitory Concentration (MIC) Test Minimum Inhibitory Concentration (MIC) Value

Table 2: The number of bacterial concentration (cells $/ \mathrm{ml}$ ) for each organism inhibited by the low aqueous extract $(100 \mathrm{mg} / \mathrm{ml})$

\begin{tabular}{|c|c|c|c|c|c|c|c|c|}
\hline \multirow{3}{*}{ Organisms } & \multicolumn{6}{|c|}{$\begin{array}{c}\text { Fixed plant concentration } \\
\text { (Low concentration: } 100 \mathrm{mg} / \mathrm{ml} \text { ) }\end{array}$} & \multirow{2}{*}{$\begin{array}{c}\text { Oradex } \\
(+) \\
\text { control }\end{array}$} & \multirow{2}{*}{$\begin{array}{c}\text { Distilled } \\
\text { water } \\
(-) \\
\text { control }\end{array}$} \\
\hline & \multirow{2}{*}{\multicolumn{8}{|c|}{\begin{tabular}{l}
\multicolumn{2}{c}{ Bacteria concentration (cells/ ml) } \\
$1 \times 10^{5}$
\end{tabular}}} \\
\hline & & & & & & & & \\
\hline S. aureus & - & - & - & - & - & - & - & + \\
\hline E. coli & + & + & - & - & - & - & - & + \\
\hline S. mutans & - & - & - & - & - & - & - & + \\
\hline L. casei & + & + & + & + & + & + & - & + \\
\hline B. fragilis & + & - & - & - & - & - & - & + \\
\hline $\begin{array}{l}\text { A. actinomyce- } \\
\text { temcomitans }\end{array}$ & + & + & + & + & + & + & + & + \\
\hline $\begin{array}{l}\text { Dental plaque } \\
\text { (Aerobic) }\end{array}$ & + & + & + & + & + & + & - & + \\
\hline $\begin{array}{l}\text { Dental plaque } \\
\text { (Facultative) }\end{array}$ & + & + & + & + & + & - & - & + \\
\hline $\begin{array}{l}\text { Dental plaque } \\
\text { (Anaerobic) }\end{array}$ & + & + & + & + & + & + & - & + \\
\hline
\end{tabular}

Table 3: The number of bacterial concentration (cells $/ \mathrm{ml}$ ) for each organism inhibited by the high aqueous extract $(200 \mathrm{mg} / \mathrm{ml})$

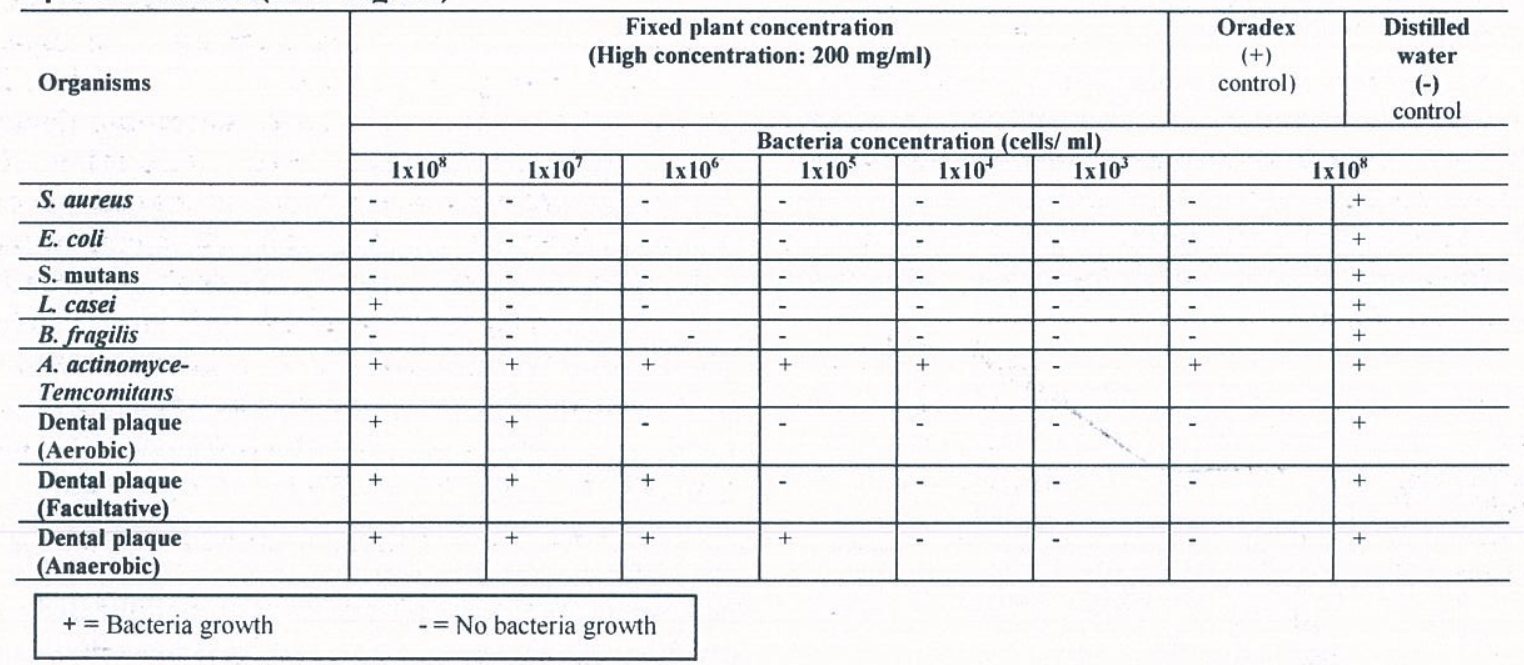

The graph showed the lowest plant concentration needed to inhibit the growth of the microorganisms. The values are the same for the two independent tests done and these values were based on the bacterial growth seen on the agar plates after an overnight incubation in the confirmation step (spot inoculation). The last plant concentration that inhibits the growth of these organisms is regarded as the MIC values. From the graph, the MIC value for S. aureus was $25 \mathrm{mg} / \mathrm{ml}$ of aqueous extract and $12.5 \mathrm{mg} / \mathrm{ml}$ of ethanol extract. These values are the lowest MIC values obtained in this study. The MIC values for $E$. coli, S. mutans and $L$. case $i$ were $100 \mathrm{mg} / \mathrm{ml}, 50 \mathrm{mg} / \mathrm{ml}$ and $200 \mathrm{mg} / \mathrm{ml}$ for the aqueous extract respectively.On the other hand, 25 $\mathrm{mg} / \mathrm{ml}$ of ethanol extract is the MIC value for both $E$. coli and $S$. mutans whereas $50 \mathrm{mg} / \mathrm{ml}$ ethanol extract inhibits $L$. casei Bacteroides fragilis required low concentration of both plant extracts to be inhibited which are $100 \mathrm{mg} / \mathrm{ml}$ of aqueous and $50 \mathrm{mg} / \mathrm{ml}$ of 
ethanol extracts. The highest MIC value comes from A. actinomycetemcomitans with $300 \mathrm{mg} / \mathrm{ml}$ of aqueous extract and $150 \mathrm{mg} / \mathrm{ml}$ of ethanol extract. This MIC values were the same for the anaerobic dental plaque pool samples. Higher aqueous extract was needed which is $300 \mathrm{mg} / \mathrm{ml}$ to inhibit both aerobic and facultative dental plaque pool samples but only $75 \mathrm{mg} / \mathrm{ml}$ of ethanol extract required to inhibit both of these samples. There was no inhibition seen by the negative controls therefore bacteria were seen growing on the plates. The positive control showed inhibition for all the tested organisms and dental plaque pool samples except $A$. actinomycetemcomitans where a few colonies were seen on the agar plates.

\section{3- Fix Plant Concentration Test}

The results for this test were determined by the highest concentration of bacteria that can be inhibited by the plant extract concentration chosen. Therefore, the readings starts from the lowest bacterial concentration which is $1 \times 103$ cells $/ \mathrm{ml}$ up to the maximum concentration of $1 \times 10^{8}$ cells $/ \mathrm{ml}$. Table 2 shows the bacterial concentration inhibited by 100 $\mathrm{mg} / \mathrm{ml}$ of aqueous cinnamon extract, which is the low aqueous extract concentration. S. aureus and $S$. mutans were the only organisms to be completely inhibited whereas $E$. coli and $B$. fragilis were inhibited up till $1 \times 10^{6}$ cells $/ \mathrm{ml}$ only. No inhibition was seen for A. actinomycetemcomitans, aerobic and anaerobic dental plaque pool samples even at the lowest bacterial concentration, $1 \times 10^{3}$ cells $/ \mathrm{ml}$. For the facultative pool sample, $1 \times 10^{3}$ cells $/ \mathrm{ml}$ of bacteria can be inhibited by $100 \mathrm{mg} / \mathrm{ml}$ of aqueous extract.

Table 3 shows the results for the inhibition by the high concentration of aqueous extract ( 200 $\mathrm{mg} / \mathrm{ml}$ ). The numbers of organisms inhibited were better compared to the low concentration where $S$. aureus, E. coli, $S$. mutans and $B$. fragilis were completely inhibited and no sign of growth seen on the agar.

The numbers of bacteria inhibited were increased in A. actinomycetemcomitans and dental plaque pool samples with the high aqueous extract given where $1 \times 10^{6}$ cells $/ \mathrm{ml}$ of aerobic dental plaque pool sample is being inhibited.The results for the ethanol extract were shown in Table 4 and Table 5 where in Table 4, the lower ethanol extract was tested. Based on the results, $100 \mathrm{mg} / \mathrm{ml}$ of ethanol extract can inhibit more organisms with $S$. aureus, $E$. coli and $S$. mutans being completely inhibited. High concentration of $B$. fragilis, $1 \times 10^{7}$ cells $/ \mathrm{ml}$ and $1 \times 10^{6}$ cells $/ \mathrm{ml}$ of $L$. case $i$ was inhibited whereas significant reductions of dental plaque pool samples were seen. The facultative pool sample bacteria were inhibited with the highest number, $1 \times 10^{6}$ cells $/ \mathrm{ml}$. In comparison, aerobic dental plaque pool samples were inhibited slightly higher compared to the anaerobic pool samples. The results presented in Table 5 showed the best inhibition of bacteria in which all the organisms tested were completely inhibited up to the highest number of bacteria, $1 \times 10^{8}$ cell $/ \mathrm{ml}$ except $a$. actinomycetemcomitans and anaerobic dental plaque pool sample. The Cinnamomum zeylanicum ethanol extract concentration that was chosen to represent the higher plant concentration was $100 \mathrm{mg} / \mathrm{ml}$. With this concentration, $1 \times 10^{7}$ cells $/ \mathrm{ml}$ of anaerobic dental plaque pool sample and $1 \times 10^{6}$ cells $/ \mathrm{ml}$ of $A$. actinomycetemcomitans were managed to be inhibited. This showed that with $100 \mathrm{mg} / \mathrm{ml}$ of the ethanol extract, low concentration of these bacteria can be completely killed and inhibited. These results were confirmed based on the growth of the organisms on the agar plates after an overnight incubation. The results for the second run were the same as the initial test done with no differences.

Table 4:The number of bacterial concentration (cells/ml) for each organism inhibited by the Low Ethanol Extract $(50 \mathrm{mg} / \mathrm{ml})$

\begin{tabular}{|c|c|c|c|c|c|c|c|c|}
\hline \multirow{3}{*}{ Organisms } & \multicolumn{6}{|c|}{$\begin{array}{c}\text { Fixed plant concentration } \\
\text { (Low concentration: } 50 \mathrm{mg} / \mathrm{ml} \text { ) }\end{array}$} & \multirow{2}{*}{$\begin{array}{c}\begin{array}{c}\text { Oradex } \\
(+) \\
\text { control) }\end{array} \\
\end{array}$} & \multirow{2}{*}{$\begin{array}{l}\text { Distilled } \\
\text { water } \\
(-) \\
\text { control } \\
\end{array}$} \\
\hline & \multicolumn{6}{|c|}{ Bacteria concentration (cells/ ml) } & & \\
\hline & $1 \times 10^{8}$ & $1 \times 10^{7}$ & $1 \times 10^{6}$ & $1 \times 10^{5}$ & $1 \times 10^{4}$ & $1 \times 10^{3}$ & \multicolumn{2}{|c|}{$1 \times 10^{8}$} \\
\hline S. aureus & - & - & - & - & - & - & - & + \\
\hline E. coli & - & - & - & - & - & - & - & + \\
\hline S. mutans & - & - & - & - & - & - & - & + \\
\hline L casei & + & + & - & - & - & $-\cdots$ & - & + \\
\hline B fragilis & + & - & - & - & - & - & - & + \\
\hline $\begin{array}{l}\text { A. actinomyece- } \\
\text { temcomitans }\end{array}$ & + & + & + & + & + & + & + & + \\
\hline Dental plaque (Aerobic) & + & + & + & + & + & - & - & + \\
\hline Dental plaque (Facultative) & + & + & - & - & - & - & - & + \\
\hline Dental plaque (Anaerobic) & + & + & + & + & + & + & - & + \\
\hline
\end{tabular}


Table 5: The number of bacterial concentration (cells/ml) for each organism inhibited by the High Ethanol Extract $(100 \mathrm{mg} / \mathrm{ml})$

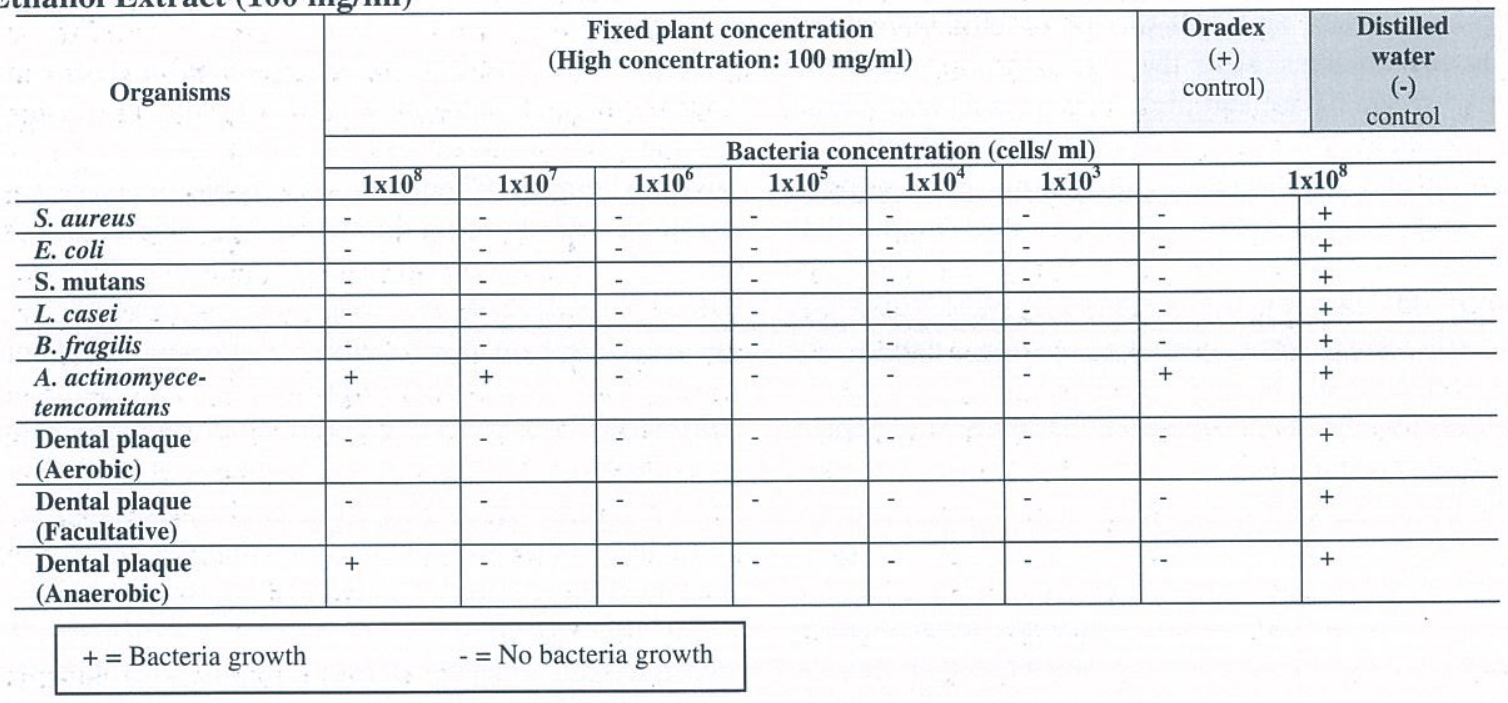

\section{Plant \\ Concentration $(\mathrm{mg} / \mathrm{ml})$}

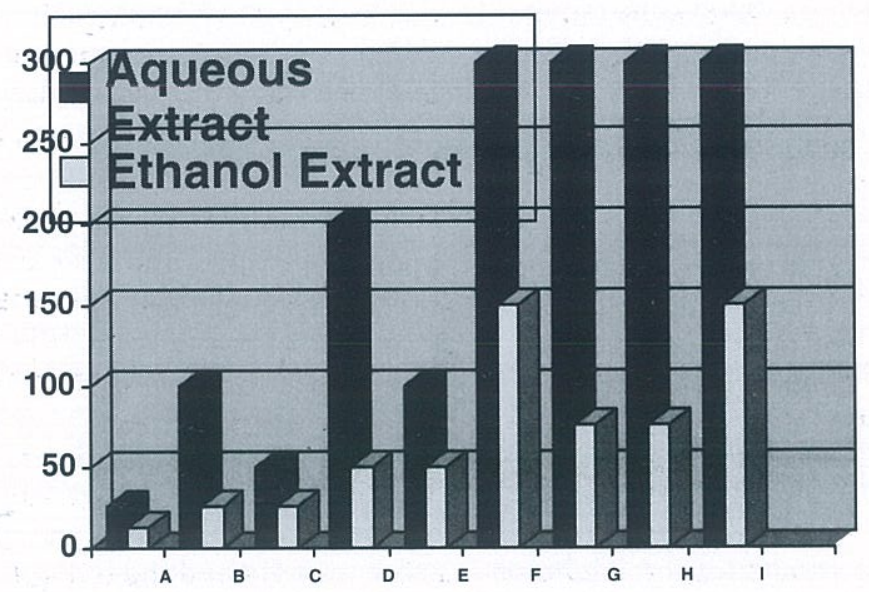

Dental Plaque Organisms

$$
\begin{aligned}
& \mathbf{A}=S . \text { aureus } \\
& \mathbf{B}=E . \text { coli } \\
& \mathbf{C}=S . \text { mutans } \\
& \mathbf{D}=L . \text { casei } \\
& \mathbf{E}=B . \text { fragilis }
\end{aligned}
$$

$\mathbf{F}=$ A. actinomyecetemcomitans

$\mathbf{G}=$ Dental plaque pool sample (Aerobic)

$\mathbf{H}=$ Dental plaque pool sample(Fcultative)

$\mathbf{I}=$ Dental plaque pool sample(Anaerobic)

Figure 2: Lowest plant concentration identified to inhibit the visible growth of tested organisms after an overnight incubation.

\section{Discussion}

In the present study, the antibacterial activities of Cinnamomum zeylanicum were evaluated against various dental plaque organisms including the dental plaque pool sample. The disk diffusion test was done to screen the antibacterial activity of the plant extract. The concentration chosen was based on literature review of previous studies where the disk diffusion test results gave a hint of the resistance or susceptibility of the tested organisms against the plant extracts. The more susceptible organisms required a lower starting value of plant extract for the Minimum Inhibitory 
Concentration (MIC) test whereas the resistance organisms such as A. actinomycetemcomitans, needed a higher concentration of extract. The MIC test was used as the main antibacterial test to evaluate the antibacterial activity because this test can determine the lowest plant concentration needed to inhibit visible (99\%) bacterial growth. From the MIC test, the Minimum Bactericidal Concentration (MBC) can also be identified but MBC was not emphasized in this study. After the MIC value of each organisms determined, a random low and high plant extract concentration was chosen to be used in the fixed plant concentration test. The values chosen for the later test is within the MIC value of the highest and lowest MIC range for all the tested organisms. The motive of this test was to evaluate the number of bacteria that can be inhibited by the chosen plant concentration and to see the effects of Cinnamomum zeylanicum extracts if used at fix concentration as a mouthwash or tooth paste. This study uses Oradex as the positive control because it's the recommended antibacterial mouthwash to control dental plaques as well as treating gingivitis. ${ }^{12}$ The antibacterial effects of Cinnamomum zeylanicum was compared with the antibacterial effects of Oradex.

Based on the antibacterial tests done, the ethanol extract required at least half of the aqueous plant extract concentration to inhibit the same organisms tested. This was well expected because the major chemical constituents in the cinnamon bark was cinnamaldehyde which dissolved in solvents like $95 \%$ ethanol. Therefore, limited amount of this compound dissolved in aqueous extracts making the antibacterial activity of this particular extract lesser compared to the ethanol extract. But the results obtained in this present study were not consistent with the previous studies which proved low concentration of Cinnamomum zeylanicum extracts and MIC values can inhibit the relatively same organisms tested in this study where the MIC values from this study was higher. Cinnamaldehyde is more soluble in pentene solvents ${ }^{13}$ compared to ethanol which explains the need of a higher concentration of the ethanol extract to exhibit the similar antibacterial effects towards the microorganisms.

The first organism to be inhibited at the lowest plant concentration was $S$. aureus followed by $S$. mutans. It showed that gram-positive cocci bacteria were the most susceptible to the cinnamon extract. Between $S$. aureus and E. coli, higher concentration of extracts needed to kill $E$. coli because $E$. coli is a gram-negative bacilli organism. But $L$. case $i$ which is also a bacillus, but a facultative anaerobe gram-positive bacterium required a higher plant extract perhaps due to its environmental conditions where it grows that causes $L$. casei to be more resistance. A. actinomycetemcomitans proved to be the most resistance organisms compared to the others because this particular bacterium is a gramnegative bacillus which grows in an anaerobic environment and posed as the most pathogenic organism. These factors may contribute to the resistance and provided better mechanisms in avoiding the antibacterial activity of cinnamon extracts. For the dental plaque pool samples, the anaerobic cultures were the most resistance leading to a higher MIC values. Microscopic observation showed more gram-negative and gram-positive bacilli organisms seen in the culture compared to the aerobic broth which comprised more of grampositive cocci bacteria.

Generally, the gram-positive organisms were less resistance towards the antibacterial properties of Cinnamomum zeylanicum extracts compared to the gram-negative organisms. The type of bacterial cell wall plays a crucial role. Grampositive bacteria's cell wall has a thick layer of peptidoglycan, including teichoic and teichuronic acids. The peptidoglycan layer provides rigidity and protects the cell contents. ${ }^{14}$ But the peptidoglycan layer is easily penetrated by antibacterial agents that managed to kill the bacteria and provide less protection due to its ineffective permeability barrier. In comparison, the gram-negative cell wall is more complex where it has an outer phospholipidic membrane that carries the structural lipopolysaccharide components. This characteristic makes the cell impermeable to lipophilic solutes, while porins constitutes a selective barrier to the hydrophilic solutes. Therefore, with these special features, the gram-negative bacteria were more resistance to certain antibacterial agents including low concentration of cinnamon extracts.Cinnamaldeyhde interacts with the cell membrane which disrupts and leaks out small ions from the inner cell components. This interaction affected the integrity of the cell which induces the depletion of intracellular ATP (adenosine triphosphate) molecules. The interaction also caused more cell constituents to be release to the environment and the alteration of intracellular $\mathrm{pH}$ to a lower $\mathrm{pH}$.

In comparison, chlorhexidine, a cationic substance that binds to bacterial cell wall and kills it. ${ }^{15}$ The mechanisms of chlorhexidine is more efficient in disrupting the organisms' cell wall. Therefore, the antibacterial properties of chlorhexidine is better 
compared to cinnamon extracts. This explanation was side by side with the presents study's results which showed that Oradex mouthwash could inhibit all the organisms tested including the dental plaque pool samples. However, even if the antibacterial actions of chlorhexidine was good, it didn't manage to inhibit completely $A$. actinomycetemcomitans growth This study showed that the ethanol extract of Cinnamomum zeylanicum has a better antibacterial properties compared to the aqueous extract in the entire antibacterial test done.

\section{Conclussion}

Cinnamomum zeylanicum ethanol extracts demonstrated a stronger antibacterial activity compared to the aqueous extract. Chlorhexidine showed a higher antibacterial effect on the microorganisms than plant extracts.

\section{References:}

1. Bernimoulin JP. Recent concepts in dental plaque. The J Clin Periodontol Suppl 2003; 30(5): 7-9.

2. Kolenbrander PE, London J. Adhere today, here tomorrow: Oral Bacteria Adherence. $J$ Bacteriol.1993; 3247-52.

3. Muller HP, Heinecke A, Furhmann A, Zoller L Intraoral distribution of Actinobacillus actinomycetemcomitans in young adults with minimal periodontitis disease. $J$ Periodont Res. 2001; 36(2): 114-23

4. Carranza, Newman M G, Clinical priodontology $8^{\text {th }}$ ed,.India.W.B.Saunders companies 1996,p 511-12.

5. Al-JebooryA. Ethnaopharmacology, ALHuria House press, Baghdad; 1994: 38.

6. Kaul P N, Bhattacharya A K, Rao B R R Volatile constituents of essential oils isolated from different parts of cinnamon. Journal of the Science of Food and Agricultural 2002; 18(1): 53-5.
7. Gulab N. J, Onkar D. D. Carolina M. J. Identification of the major fungitoxic component of cinnamon bark oil. $J$ Fitopatology 2005; 30(4).

8. Lopez P., Sanchez C., Battle R. and Nerin C. Solid- and vapor-phase antimicrobial activities of six essential oils: susceptibility of selected foodborne bacterial and fungal strains. $J$ Agricultural and Food Chemistry 2005; 53(17): 6939-46.

9. Singh $H B$, Srivastava $M$, Singh $A B$ and Srivastava AK. Cinnamom bark oil, a potent fungitoxicant against fungi causing respiratory tract mycoses. The Allergy 1995: 50(12): 995999.

10. Morozumi S. Isolation, purification, and antibiotic activity of omethoxycinnamaldehyde from cinnamon. $J$ Applied and Environmental Microbiology 1978;36;(4): 577-83.

11. Kamath JV, Rana AC, Chowdhury AR. Prohealing effect of Cinnamomoun Zeylanicum bark.Phytotherapy Research 2003; 17 (8) : 970-72.

12. Arweiler, Nicole B, Boehnke,Sculean, Anton, Hellwing, Elmar. Diffefences in efficacy of two chlorhexidine mouth rinse solutions. $J$ Clin Periodontol 2006; 33(5):334-9.

13. Jayaprakasha G K, Rao L J, Sakariah K K. Chemical composition of the volatile oil from the fruits of Cinnamomum zeylanicum blume. Journal of Flavor and Fragrance 1998; 12(5): 331-3.

14. Simic A. Sakovic M D, Ristic M., Marin P D, Jovanovic G S, Yukojevic J. The chemical composition of some Lauraceae essential oils and their antifungal activities. $J$ Phytotherapy Research 2004; 18(9): 713-17.

15. Cury J A, Rocha E P. Effect of Saccharin on Antibacterial Activity of Chlorhexidine Gel. $J$ Brit Dent 2000;11(1): 29-34 